\title{
Páttaskil: Hvers vegna velja konur í forystu að fara úr æðstu stjórnunarstöðum á miðjum aldri?
}

\author{
Árelía Eydís Guðmundsdóttir, Íris Hrönn Guðjónsdóttir ${ }^{1}$
}

\begin{abstract}
Ágrip
Konur eru í minnihluta forystu í íslenskum skipulagsheildum og vísbendingar eru um að pær séu líklegri en karlar til að yfirgefa forystuhlutverkið að eigin frumkvæði. Pá fjölgar konum til pess að gera hægt í æðstu stjórnendastöðum í fyrirtækjum, sérstaklega sé litið til skráðra félaga. Konur eru pó í forystu víða og eru pær fleiri í opinberum fyrirtækjum heldur en einkafyrirtækjum. Ísland hefur mælst með minnst kynjabil í heimi síðastliðin 12 ár samfellt og konum er óvíða búinn jafn góður lagalegur réttur og á Íslandi. Í pessari grein var leitast við að varpa ljósi á hvað fengi íslenska kvenleiðtoga, sem komnar eru á eða yfir miðjan aldur, til að gera róttæka breytingu á starfsferli sínum með pví að hverfa, að eigin frumkvæði, úr æðstu stjórnunar- og áhrifastöðum og snúa sér að ólíkum verkefnum. Eigindlegri aðferðafræði var beitt við rannsóknina og tekin voru viðtöl við 14 konur sem allar höfðu gegnt forystustörfum á sínu sviði. Helstu niðurstöður voru pær að umfangsmiklar breytingar á starfsferli hafi oftast haft fjárhagslegar og ímyndarlegar afleiðingar í för með sér. Viðmælendur hafi farið í sjálfsskoðun knúna af innri hvöt, sem tengdist gjarnan ytri páttum eins og ónotum sem peir höfðu upplifað í starfsumhverfi eða innri páttum eins og heilsuleysi eða miklu vinnuálagi. Niðurstöður gefa til kynna að pegar horft er til starfsferils leiðtoga sé mikilvægt að gera ráð fyrir að peir vilji breyta til eða haga lífi sínu og starfi með nýjum hætti á miðjum aldri. Fjölbreyttari leiðir leiðtoga til pess að sinna persónulegum proska og endurmati á miðjum aldri er æskileg til að missa ekki út reynslu og pekkingu kvenleiðtoga.
\end{abstract}

\section{Abstract}

Women represent the minority of leaders within Icelandic organizations and there are indications of them being more likely than males to opt out of leadership. The progress towards an increased number of women executives is relatively slow in businesses, especially in companies listed at the stock market. However, women lead in many fields, and they lead public organizations more frequently than private organizations. Iceland ranks, for the $12^{\text {th }}$ consecutive year, as the most gender-equal country in the world and the regulatory framework for equality is rarely nearly as good in other countries compared to Iceland. The aim of this paper is to shed a light on what motivates Icelandic women in top management or influential positions

1 Árelía Eydís Guðmundsdóttir er dósent við Viðskiptafræðideild Háskóla Íslands. Netfang: arelia@hi.is. Íris Hrönn Guðjónsdóttir er viðskiptafræðingur og innviðastjóri í Háskóla Íslands. Netfang: irishg@hi.is

This work is licensed under a Creative Commons Attribution 4.0 License.

DOI: https://doi.org/10.24122/tve.a.2021.18.2.4

(C) Tímarit um viðskipti og efnahagsmál

www.efnahagsmal.is 
to "opt out" of their career paths after reaching middle age. The study is based on a qualitative methodology and 14 women were interviewed who were in leading positions within their field of expertise. The main findings were that radical changes to career paths often involved financial and identity consequences. The women went through a self-evaluation motivated by an inner drive, sometimes related to external conditions such as unease within their work environment or internal conditions such as compromised health or a high workload. Looking at leaders' careers, the results indicate that it's important to assume they feel the need for change or a development in their life and career differently during middle age. In order to maintain organizations' talent pool, it is important not to lose expertise and to consider a variety of pathways for leaders to attend to their mid-life personal growth and re-evaluation.

JEL flokkun: M14; M12

Lykilorð: Forysta; kvenleiðtogar; að velja út;; starfsferill; sjálfsskoðun.

Keywords: Leadership; female leaders; opt-out; career path; self-evaluation.

\section{Turning point What drives female leaders to opt out of top executive positions during middle age}

\section{Inngangur}

Konum hefur fjölgað í forystuhlutverkum á Íslandi á síðusta áratug. Engu að síður standa konur víða höllum fæti gagnvart karlmönnum varðandi forystustörf, sérstaklega pegar kemur að fjármálageiranum pótt Ísland búi við eitt mesta kynjajafnrétti í heimi (Hagstofa Íslands, e.d.; World Economic Forum, 2021).

Alpjóðlega hafa komið fram vísbendingar um ákveðið brottfall kvenna úr forystu í karllægu starfsumhverfi (Zimmerman og Clark, 2016). Рað virðist pó vera að breytast pví skv. Marsh og Bloomberg (2020) fer hlutfall kvenna vaxandi í áhrifastöðum í fjármálalgeiranumvegna stóraukins áhuga fjárfesta á ábyrgum fjárfestingum (e. SRI socially responsible investments) og viðskiptageirans á hugmyndafræðinni (UFS) (e. ESG environmental, social and governance) sem ábyrgar fjárfestingar byggja á. Hlutfall kvenna er miklu meira í ábyrgum fjárfestingum heldur en almennt í fjármálageiranum og konur virðast búa yfir eiginleikum sem fyrirtæki sækjast eftir í auknum mæli (Hanson, 2019).

Störf skapa tekjur en huglægir pættir hafa áhrif á starfsval eins og hugmyndin um tilgang og pýðingu, sjálfsfyllingu, áskoranir (Defillippi og Arthur, 1994; Dik og Duffy, 2009). Starfsferillinn er uppspretta sjálfsmyndar og er í raun stór hluti af sjálfsmynd fólks (Defillippi og Arthur, 1994). Í nútímasamfélagi Vesturlanda fara lífslíkur vaxandi og starfsferill framtíðarinnar mun purfa að taka mið af pví. Proski einstaklinga hefur fengið aukið vægi og möguleikum til að hafa áhrif á eigið lífshlaup hafa vaxið mjög - sérstaklega sé litið til kvenna. Ljóst er að tilfinningar og upplifanir fólks skipta meira máli en áđur, sem hefur áhrif á störf, samfélagsgerð o.fl.

Í rannsókninni sem pessi grein byggir á er miðað við einstaklinga sem höfðu sinnt leiðandi hlutverkum í atvinnulífinu og gegnt framkvæmdastjórastöðu eða sambærilegu í stórfyrirtækjum eða stofnunum. Ýmsar vísbendingar eru um að konur í æðstu stjórnunarstöðum kjósi að fara úr peim á miðjum aldri (Frkal og Criscione-Naylor, 2020; Zimmerman og Clark, 2016). Til pess að kanna petta á Íslandi var sjónum beint að konum í æðstu stjórnunarstöðum, sem um eða eftir miðjan aldur kusu að gera róttækar breytingar á starfsferli sínum, prátt fyrir að hann hafi verið farsæll og árangursríkur. Rannsóknarspurningin sem pessi grein leitast við að svara er: Hvers vegna velja konur i forystu að fara úr æðstu stjórnunarstörfum á miðjum aldri? Rannsóknin byggir á eigindlegri aðferðafræði og unnið var með viðtöl sem tekin voru við konur sem uppfylltu skilgreind viðmið. Í viðleitni til að svara rannsóknarspurningunni var lagt upp með að skoða forystu, konur í forystu og muninn 
á körlum og konum í forystu. Eigindleg aðferðafræði var valin til að leita skilnings á viðfangsefninu og tekin voru fjórtán ítarviðtöl við konur sem uppfylltu forsendurnar.

I stuttu máli má segja að svar við rannsóknarspurningunni sé að umfangsmiklar breytingar á starfsferli hafi oftast haft fjárhagslegar og ímyndarlegar afleiðingar í för með sér. Viðmælendur hafi farið í sjálfsskoðun knúna af innri hvöt, sem tengdist gjarnan ytri páttum eins og ónotum sem pær upplifðu í starfsumhverfi. Dæmi um slíkt er að sumir viðmælendur upplifðu að gildi peirra og skipulagsheildarinnar færu ekki saman. Einnig fóru viðmælendur úr forystu vegna innri pátta eins og heilsuleysis eða mikils vinnuálags. Viðmælendur kusu pannig að ljá lífi sínu aðra merkingu en starfið eitt og sér bauð peim.

Greinin skiptist í fimm aðalkafla. Að loknum pessum inngangi verður farið yfir fræðilegan bakgrunn. Síðan er aðferðafræðinni lýst, pá gert grein fyrir helstu niðurstöðum og loks er gerð samantekt og umræður.

\section{Fræðilegt yfirlit}

Frá aldamótunum 2000 hefur atvinnupátttaka kvenna á íslenskum vinnumarkaði verið mjög nærri atvinnupátttöku karla, eða í kringum 80\% (Hagstofa Íslands, e.d.). Á Íslandi er atvinnupátttaka næstmest, á eftir Svípjóð, í ríkjum OECD. Árið 2019 var heildaratvinnupátttaka á Íslandi 88,9\% samanborið við 78,4\% í OECD ríkjunum (OECD, e.d.-a).

Rannsóknir sýna að með pví að auka kynjajafnrétti á vinnumarkaði og bæta stöðu kvenna megi auka hagvöxt og bæta efnahagsstöðugleika (Olafssdottir, 2018). Ísland trónir á toppi pjóða heims með minnstan kynjahalla árið 2021, tólfta árið í röð samkvæmt skýrslu Alpjóðaefnahagsráðsins, en pá mældist íslenska vísitalan 0,89 (World Economic Forum, 2021; Porgerður Einarsdóttir, e.d.). Hlutfall kvenna í forystu skipulagsheilda á Íslandi er 10-20\% (Hagstofa Íslands, e.d.). Pótt konum í framkvæmdastjórastöðum fari fjölgandi, fækkar peim eftir pví sem fyrirtækin stækka og pær eru næstum helmingi færri í stærstu fyrirtækjunum en peim minnstu (Hagstofa Íslands, e.d.; Velferðarráðuneytið, 2018). Pá benda gögn til pess að ákveðin slagsíða sé á einkafyrirtækjum, pví konur í stöðum framkvæmdastjóra einkafyrirtækja voru ríflega $20 \%$ meðan hlutfall forstöðukvenna ríkisstofnana var ríflega 40\%. Ein kona stýrir fyrirtæki sem skráð er í Kauphöll Íslands, en Íslandsbanki var skráđur í Kauphöllina 22. júní sl. (Arnar Björnsson, 2021). GemmaQ-mat (e. gender equality measure monthly automated quotation) á íslenska hlutabréfamarkaðinum hækkaði af pessu tilefni um 0,1 prósentustig pegar pað fór úr 6,7 stigum í 6,8 stig, en fyrirtækið metur kynjafjölbreytni í forystu fyrirtækja (Gemmaq, e.d.-a; Gemmaq, e.d.-b).

Noregur og Ísland voru meðal fyrstu ríkja heims til að binda kynjakvóta í stjórnum fyrirtækja í lög og eru einu Norðurlöndin sem hafa gert pað til fulls (Jafnréttisstofa, e.d.-c). Hér á landi hafa kynjakvótar í stjórnum fyrirtækja verið bundnir í lög frá árinu 2010 og Ísland var annað landið á eftir Noregi til að lögbinda pá (Jafnréttisstofa, e.d.-b). Рað ár sampykkti Alpingi lög um breytingu á lögum um hlutafélög og lögum um einkahlutafélög par sem starfa fleiri en 50 starfsmenn. Lögunum er ætlað að fjölga konum í stjórnum fyrirtækja (Jafnréttisstofa, e.d.-b; lög um einkahlutafélög nr. 138/1994; lög um hlutafélög nr. 2/1995). Sambærileg lög voru sett árið 2011 um kynjakvóta í stjórnum lífeyrissjóða (Jafnréttisstofa, e.d.-b; lög um skuldatryggingu lífeyrisréttinda og starfsemi lífeyrissjóða nr. 129/1997). Árið 2013 tók pessi breyting svo gildi fyrir sameignarhlutafélög og opinber hlutafélög par sem starfa fleiri en 50 starfsmenn (Jafnréttisstofa, e.d.-b; lög um hlutafélög nr. 2/1995; lög um sameignarfélög nr. 50/2007). Í greinargerð með frumvarpi sem varð að lögum um kynjakvóta í stjórnum íslenskra fyrirtækja var tekið fram að markmið pess væri að stuðla að jafnari hlutföllum kvenna og karla í áhrifastöðum í hlutafélögum og einkahlutafélögum (Velferðarráðuneytið, 2018). Sé litið til gagna um hlutföll kvenna í stjórnum fyrirtækja í víðara samhengi kemur í ljós að árið 2020 voru konur 26,5\% stjórnarmanna fyrirtækja á hlutafélagaskrá sem greiddu laun, 26,2\% í fyrirtækjum með færri en 50 launamenn og 34,1\% í fyrirtækjum með 50 launamenn eða fleiri (Hagstofa Íslands, 2021).

Á Íslandi er kynjajafnrétti bundið í ýmis lög og reglugerðir. Ítarleg lög um jafna stöðu 
og jafnan rétt kynjanna tóku gildi árið 2021 (lög um jafna stöðu og jafnan rétt kynjanna nr. 150/2020). Hornstein ákvæða um jafnrétti kynjanna í íslenskum lögum má finna í stjórnarskrá lýðveldisins Íslands sem leggur jafnframt áherslu á jafnrétti kynjanna (Stjórnarskrá lýðveldisins Íslands nr. 33/1944). Jafnlaunavottun var lögfest 2017 (Jafnréttisstofa, e.d.-a; lög um jafna stöðu og jafnan rétt kynjanna nr. 150/2020).

\subsection{Forysta kvenna}

Undanfarna áratugi hafa konur í forystu skipulagsheilda verið viðfangsefni rannsókna. Engu að síður er ýmsum spurningum enn ósvarað. Eldri rannsóknir hafa einkum beint sjónum að kenningum sem lúta að náttúrulegum hæfileikum, fjölskylduábyrgð, staðalímyndum, mismunun, forystustílum, uppbyggingu og menningu og vísað til pessara pátta til skýringar á kynjamun (Bryman o.fl., 2011; Gipson o.fl., 2017). Lágt hlutfall kvenna í forystu í atvinnulífinu vekur athygli og reynt hefur verið að finna ýmsar skýringar á pví. Kossek o.fl. (2017) birtu í greininni „" Opting out” or "pushed out?"“ samantekt á rannsóknum um persónubundna pætti og pætti innan skipulagsheilda sem hafa áhrif á jafnrétti í starfsferli kvenna. Samantektin var gerð út frá premur sjónarhornum, p.e. starfsvali, kynjahlutdrægni og sampættingu vinnu og einkalífs. Pessar rannsóknir gera greinarmun á pví hvort konurnar völdu sig út eða var ýtt út úr forystuhlutverkum innan skipulagsheilda.

Konum reynist erfiðara en körlum að fóta sig í karllægum geirum og finnst pær purfa meiri stuðning (Frkal og Criscione-Naylor, 2021; Olafsdottir, 2018). Pá sýnir bandarísk rannsókn að u.p.b. 50\% kvenleiðtoga mæta hindrunum sem koma í veg fyrir að pær komist í stjórnunarstöður (Elmuti o.fl., 2009). Ímynd farsæls stjórnanda er yfirleitt tengd karllægni og pessi staðalímynd er lífseig og viðheldur pannig forskoti karla. Pví hefur verið haldið pví fram að konur skorti innri hvata til að ná árangri en rannsóknir benda til annars (Frkal o.fl., 2020). Aðrir benda á árekstra milli vinnu og einkalífs, p.e. að konur séu enn aðalumönnunaraðilar á heimilum og að erlendis kjósi fjölmargar konur að yfirgefa starfsvettvang sinn í págu fjölskyldunnar (Elmuti o.fl., 2009). Rannsóknir sýna að íslenskar konur verja meiri tíma en karlar í ólaunaðri vinnu sem tengist heimili og fjölskyldu og að umönnunarábyrgðin sé mikil (Magnús H. Jónasson, 2021).

Karlar eru ráđandi í fjármálageiranum um allan heim nema einu sviði sem er vaxandi, er svokallað UFS (Marsh og Bloomberg, 2020). UFS stendur fyrir umhverfislega og félagslega pætti og stjórnarhætti og eru viðmið sem fjárfestar nota til að meta fjárfestingar út frá aðferðafræði ábyrgra fjárfestinga (IcelandSIF, e.d.). Hlutfall kvenna er miklu meira í ábyrgum fjárfestingum heldur en almennt í fjármálageiranum. Ýmissa skýringa hefur verið leitað, en ljóst er að um ræðir eiginleika sem fyrirtæki sækjast eftir í vaxandi mæli (Hanson, 2019).

Deilt hefur verið um pað hvort nálgun karla og kvenna í forystu sé ólík (Burk og Collins, 2001) og litlar sannanir eru fyrir mismunandi frammistöðu í víðu samhengi eftir kyni (Gipson o.fl., 2017). Harvard Business Review birti árið 2019 rannsóknargrein og samkvæmt niðurstöðum hennar kemur ekki fram munur eftir kynjum. Gögn rannsóknarinnar sýna með sannfærandi hætti að skýringanna á færri konum í stjórnunarstörfum sé leita í sjálfsmati kvenna. Sjálfsmatið sem notað er til grundvallar mælir m.a. sjálfstraust sem leiðtogar hafa í starfi. Munurinn á sjálfsmati kynjanna reyndist mikill á yngri árum en mættist á miðjum aldri. Sjálfsmat á hæfni karla hækkaði um 8,5 prósentustig frá 25 - 60 ára meðan pað hækkaði um 29 prósentustig hjá konum (Zenger og Folkman, 2019). Komið hefur í ljós í ýmsum íslenskum rannsóknum að konur eigi bæði erfiðara með að fá ráðningu í stjórnunarstöður og að fá stöðuhækkun (Ólöf Júlíusdóttir o.fl., 2018; Guðbjörg Linda Rafnsdóttir og Ólöf Júlíusdóttir, 2018; Ásta Dís Óladóttir o.fl., 2021). Svo virðist sem að kynjahalla í stjórnunarstöðum á Íslandi megi helst skýra út frá pví að konur rekist á „,viðvarandi glerpak pegar pær sækist eftir valdastöðum“ (Póra H. Chistiansen o. fl., 2021, bls. 111.) Einnig hefur komið fram að færri konur sækist eftir valdastöðum, að viðhorf karl- 
manna í valdastöðum séu hindrun og að konur sinni frekar heimilsstörfum sem hafi áhrif á framgang peirra (Guðbjörg Linda Rafnsdóttir o.fl., 2015).

Líta verður til kenninga um starfs- og lífsferils fólks til að glöggva sig betur á kynjahalla í æðstu stjórnunarstöðum.

\subsection{Starfsferill}

Starfsferillinn hefur próast frá pví að vera línulegur; nám, starfsferill og starfslok, yfir í að vera mun sveigjanlegri (Baruch, 2004). Starfsferill skipar veigamikinn sess í lífi fólks, sem, auk pess að skapa tekjur, getur veitt sjálfsfyllingu, áskoranir og tilgang. Hann getur jafnframt verið uppspretta sjálfsmyndar, sköpunar, lífsáskorunar, samfélagsstöðu og félagslegs tengslanets (Defillippi og Arthur, 1994). Konur skilgreina starfsframa huglægar en karlar, p.m.t. lífsgæði, starfsánægju, og persónulegan proska (Marvin, 2001). Pegar karlar eru spurðir hvers vegna konur kjósi að hætta í stjórnunarstöðum telja peir pað vera vegna fjölskylduábyrgðar eða betri tækifæra til framgangs í starfi. Konur telja pað aftur á móti vera vegna parfa á aukinni vitsmunalegri örvun og auknu samspili milli eigin gilda og skipulagsheildarinnar. Rannsóknir benda til að konur í stjórnunarstöðum upplifi meiri streitu heldur en karlar, sem megi rekja til væntra og raunverulegra hlutverka kvenna í samfélaginu og til peirrar staðreyndar að konur séu enn í miklum minnihluta stjórnenda skipulagsheilda (Frkal o.fl., 2020; Nelson og Burke, 2000). Sama virðist eiga við um íslenskt atvinnulíf (Guðbjörg Linda Rafnsdóttir o.fl., 2015).

Kenningarnar um starfsval eiga pað sameiginlegt að einblína á áhrif innri markmiða einstaklingsins, parfir hans og viðleitni til að fylgja pví sem hann velur og honum líkar í tengslum við starfsferil. Раð gefur tilefni til að draga ályktun um að val einstaklingsins og innri pættir hafi mikið vægi. Starfsval ákvarðast einnig af ytri páttum eins og efnahagsástandi, breyttu starfsumhverfi, lífshlutverki einstaklingsins og pörfum og væntingum fjölskyldu hans (Duffy og Dik, 2009) auk pess sem aðstæður geta skapast sem mynda rof í starfsferil fólks og leiða til starfsferilsáfalls (Nalis o.fl., 2021). Allskonar huglægir pættir hafa verið tengdir við áhrif á starfsval eins og hugmyndin um tilgang og pýðingu (Dik og Duffy, 2009) án pess að sameiginleg niðurstaða hafi fengist. Samkvæmt Thomas (1980) getur pörfin fyrir að breyta starfsferli átt rætur að rekja til persónulegrar löngunar eða ytri aðstæðna. Рað næsta sem hann komst pví að finna sameiginlega ástæða fyrir starfsferilsbreytingum, var innri vinnuhvati með vísan til Herzberg o.fl. (1959); Thomas (1980). Mikilvægt er að skilja betur hvað fær fólk til pess að skipta um störf eða breyta starfsferli sínum, og par er sjálfsmynd fólks einn af skýringarpáttunum.

Sjálfsmynd er sú hugmynd sem einstaklingur hefur um sjálfan sig í líkamlegu, félagslegu, andlegu og siðferðilegu tilliti (Gecas, 1982). Að skipta um starfsvettvang felur í sér að endurhugsa vinnusjálfið. Árangursríkt starfsbreytingaferli krefst spurninga um sjálfsmyndina. Spurninga eins og: Hver er ég? Hver held ég að ég ætti að vera? Hver vonaðist ég til að verða? Starf einstaklinga er stór hluti af sjálfsmynd peirra og skilgreinir hana að hluta (Ibarra, 2003). Ibarra (2005) próaði kenningu um breytta sjálfsmynd í tengslum við sjálfsprottna starfsferilsbreytingu. Með breytingu á sjálfsmynd er átt við ferli sem felur í sér að segja skilið við sjálfsmyndina eins og hún er, samhliða pví að rýna í möguleg sjálf, og að endingu samsamast öðru sjálfi. Ibarra (2015) kynnti til sögunnar ómöguleg sjálf, sem eykur skilning á skorti af konum í æðri leiðtogahlutverkum. Hún bar kennsl á eiginleika í uppbyggingu sjálfsmyndar sem hindrar breytingarferli kvenna úr lægri stöðum í hærri stöður. Omögulega sjálfinu er ætlað að lýsa peim menningarviðmiðum um sjálfsmynd leiðtoga sem voru mörgum konum óaðgengileg pegar karllægni var ráðandi í skipulagsheildum. Í stað pess að stíga inn í árangurshugmyndir innan karllægra skipulagsheilda tileinkuðu konur sér ímynd og sjálfsmynd umhverfisins og forðuðust pannig vanpóknun annarra. Viðleitni kvennanna til að viðhalda ímynd hins sanna leiðtoga gróf hins vegar undan færni peirra til að skapa sjálfsmynd sem var í takt við pann fagmann sem pær leituðust við að verða (Ibarra, 2015). 


\subsection{Lífsferill}

Mestan hluta mannkynssögunnar hefur lífsferlinum verið skipt í tvennt, p.e. barnæsku og fullorðinsár. Með tímanum urðu pessi skil óskýrari (Gratton og Scott, 2016). Á tíunda áratug síðustu aldar setti Laura Carstensen (1995) fram kenningu sína um félagstilfinningaval (e. socioemotional selectivity) sem snýst um sálfræðilegt ferli sem hefur áhrif á félagslegt val og félagslega hegðun. Samkvæmt henni eru margvíslegir hvatar að félagslegum tengslum, allt frá grundvallarpörfinni fyrir að lifa af, til sálfræðilegra markmiða eins og próun sjálfsvitundar og tilfinningastjórnunar (Carstensen, 1995). Samkvæmt kenningunni gegnir upplifun einstaklinga á tíma grundvallarhlutverki í vali og eftirfylgni félagslegra markmiða. Félagslegir hvatar, sem breytast á lífsferlinum séu einkum af tvennum toga pekkingaröflun og tilfinningastjórnun og vægi pessara pátta breytist eftir pví sem líður á lífsferilinn (Carstensen o.fl., 1999). Umliðin næstum 200 ár, eða síðan 1840, hafa lífslíkur aukist jafnt og pétt (Gratton og Scott, 2016). OECD gerir ráð fyrir að lífslíkur íslenskra stúlkna séu 84,5 ár (OECD, e.d.-b) og Hagstofan gerir ráð fyrir að lífslíkur haldi áfram að vaxa og að árið 2069 verði meðalævilengd kvenna verði orðin 88,7 ár (Hagstofa Íslands, 2020).

Til að draga umfjöllun um lífsferilinn saman, hafa hugmyndir fólks um starfsferil og lífsferil breyst á undanförnum árum samfara lengra lífi og breyttri samfélagsgerð. Áður höfðu konur ekki sömu tækifæri og karlar til pess að ná langt á vinnumarkaði og hafa undanfarnir áratugir verið hraðfara skref í átt til jafnréttis á vinnumarkaði. Starfsferill kvenna er flóknari að pví leiti að pær eignast börn og fara pá út af vinnumarkaði um tíma. Rannsóknir hafa verið gerðar á hvaða áhrif slíkt rof hefur á starfsferil peirra (Zimmerman o.fl., 2016). Færri rannsóknir hafa verið gerðar á pví fyrirbrigði sem víða hefur verið að koma fram, að konur ákveði sjálfviljugar að yfirgefa forystustörf pegar pær hafa komist til æðstu metorða (Frkal o.fl., 2020; Kossek o.fl., 2017; Zimmerman o.fl., 2016).

\section{Aðferðafræði}

Markmið rannsóknarinnar var að skoða hugarfar og sýn kvenna í áhrifamiklum stjórnendastöðum varðandi val á breyttum starfsvettvangi. . Leitast var við að varpa ljósi á hvatana að baki pví að konur í áhrifa- eða stjórnunarstöðum á íslenskum vinnumarkaði, taki sjálfstæða ákvörðun um að yfirgefa starfsvettvang sinn, um eða eftir miðjan aldur. Eigindleg rannsóknaraðferð var valin, en samkvæmt peirri aðferðafræða er hægt að fá góða innsýn í reynsluheim pátttakenda.. Tekin voru ítarviðtöl en úrtakið var fundið með aðferð snjóboltagerðar. Í pví felst að velja lykilpátttakendur sem eru sérstakir fyrir viðfangsefnið og falla að skilgreindum viðmiðum og biðja pá í viðtölunum að vísa rannsakanda á fleiri pátttakendur (Merriam, 2009).

Tekin voru 14 viðtöl og samanlagður viðtalstími var 18 klukkustundir og 20 mínútur. Viðtölin voru hálfopin og voru pau flest tekin auglitis til auglitis og hljóð tekið upp á stafrænt form. Prjú viðtöl voru tekin á samskiptaforritinu Microsoft Teams. Leitað var eftir pátttöku kvenna á íslenskum vinnumarkaði, sem voru á miðjum aldri eða eldri og höfðu sjálfar kosið аð yfirgefa starfsvettvang sinn, sem hafði verið stjórnunarstaða eða áhrifastaða, óháð pví hvað pær tóku sér síðar fyrir hendur. Nánar tiltekið var leitað að pátttakendum sem höfðu gert talsvert mikla breytingu á sínum starfsferli en ekki pátttakendum sem höfðu skipt um starf í sama geira. Um er að ræða fámennan og pröngan hóp einstaklinga sem uppfylla tiltekin og sérstök skilyrði. Fljótlega eftir að viðtalsferlið hófst var ljóst að pátttakendur höfðu valist til rannsóknarinnar sem, að mati rannsakanda, féllu ekki nægilega vel að peim skilgreindu viðmiðum sem lagt var upp með. Misræmið fólst einkum í pví að sumir pátttakendur höfðu í raun ekki gert eins mikla breytingu á sínum starfsferli og vænst var. Viðmælendur voru á aldrinum 46-70 ára. Trúnaður ríkti og pær konur sem tóku pátt, gögn og niðurstöður rannsóknarinnar voru gerð ópersónugreinanleg og í niðurstöðukafla eru ekki birt rétt nöfn viðmælenda, heldur dulnefni. Að viðtölum 
loknum voru pau afrituð nákvæmlega, frá orði til orðs og stuðst var við úrvinnsluforritin Tiro og Transcribe. Að afritun lokinni voru viðtölin kóðuð með opinni kóðun, sem fólst í að lesa viðtalið línu fyrir línu og skrá grunngreiningar. Að pví loknu voru greind pemu, p.e. breytingahvatar, heilsa og fjölbreytt forysta sem byggðu á peim stefnum sem ítrekað komu fram í svörum viðmælenda. Undir hvert pema voru greindir flokkar sem voru litakóðaðir (Merriam, 2009).

Tafla 1. Yfirlit yfir viðmælendur

\begin{tabular}{ll}
\hline Dulnefni & Aldur \\
Agnes & 66 \\
Birna & 49 \\
Clara & 56 \\
Dísa & 67 \\
Ellen & 70 \\
Fjóla & 47 \\
Gunnhildur & 54 \\
Hanna & 51 \\
Inga & 56 \\
Jóhanna & 53 \\
Katrín & 46 \\
Lára & 57 \\
María & 51 \\
Nína & 52 \\
\hline
\end{tabular}

\subsection{Annmarkar}

Helstu annmarkar rannsóknarinnar eru mat á pví hvað felst í mikilli breytingu á starfsferli og hvað ekki og matið pví huglægt. Eins og kemur fram hjá Carless og Arnup (2011); Fouad og Bynner (2008); Heppner o.fl. (1994); eru skilgreiningar á breyttum starfsferli með ýmsum hætti og samræmd skilgreining ekki til. Svipaður annmarki er mat pátttakenda á pví hvort peir hafi valið sig út eða verið ýtt út sem erfitt getur reynst viðmælendum að leggja hlutlaust mat á. Parna á milli eru tengsl sem er áskorun að aðgreina með afgerandi hætti (Kossek o.fl., 2017). Pá hefði fjölmennara úrtak mögulega styrkt rannsóknina, pótt fræðimenn séu ekki á eitt sammála um hversu stórt úrtak sé nógu stórt í eigindlegum rannsóknum (Boddy, 2016; Sandelowski, 1995).

Almennir annmarkar eigindlegra rannsókna eru m.a. að pær eru viðkvæmar fyrir heiðarleika rannsakanda. Pá byggjast gögnin á frásögn af atburðum sem byggist á minni viðmælanda, hugmyndum hans um mikilvægi og upplifun hans. Pví er ekki hægt að alhæfa út frá gögnum og niðurstöðum eigindlegra rannsókna.

\section{Niðurstöður}

Átta viðmælendur reyndust hafa gert mikla breytingu á starfsferli sínum. Viðmælendur sem höfðu gert mikla breytingu á starfsferli sínum höfðu farið í djúpa innri sjálfsskoðun í aðdraganda sinna breytinga og litlar breytingar tengdust eðlilegri framvindu starfsferils eða aðstæðum í lífi viðmælendanna. Innri pörf eða sjálfsskoðun kviknuðu gjarnan í tengslum við rekstrarumhverfi eða starfið sjálft og vöktu viðmælendur til umhugsunar. Helmingur peirra viðmælenda sem gerðu mikla breytingu á sínum högum voru með bein tengsl við fjármálageriann og hafði pessi hópur ákveðna sérstöðu pegar kom að 
viðhorfi til kynjamunar og karla. Heilsuleysi og/eða mikið vinnuálag kom við sögu hjá átta pátttakendum og var greinilegur áhrifavaldur í ákvörðunum fjögurra. Prjár pessara fjögurra tilheyrðu peim hópi viðmælenda sem gerðu mikla breytingu. Pátttakendur tilheyrðu tveimur kynslóðum og er ákveðinn munur á viðhorfi peirra og upplifun peirra á kynjamun og körlum. Engin viðmælendanna taldi kynferði sitt hafa unnið gegn sér. Uppgangskynslóðin taldi pað hafa unnið með sér en ekki X-kynslóðin. Aldur og aðstæður kvennanna voru, að öðru leyti en pví sem lagt var upp með í leit að pátttakendum, afar mismunandi og vegna fjölbreyttra ytri og innri aðstæðna í lífi pátttakenda er ekki unnt að tengja breytingar á starfsferli viðmælenda við persónuleg tímamót eða tiltekinn aldur.

\subsection{Breytingahvatar}

Áberandi var að djúp innri sjálfsskoðun í aðdraganda breytinga hafði ekki átt sér stað hjá peim hluta viðmælenda sem höfðu gert litla breytingu, ólíkt peim sem gerðu mikla breytingu. Litlar breytingar voru knúnar af eðlilegri framvindu starfsferils eða aðstæðum í lífi viðmælendanna. Miklar breytingar voru í ríkum mæli knúnar af innri pörf eða vangaveltum um tilgang og markmið og aðstæður ýttu gjarnan við peim. Pá höfðu miklar breytingar gjarnan í för með sér afleiðingar á borð við breytta ímynd, óvissu og tekjumissi. Рað kann að vera til marks um hvað hvatarnir, sem voru undanfari ákvörðunarinnar, vega pungt. Átta viðmælendur höfðu gert miklar breytingar á starfsferli sínum. Hjá sjö peirra hafði eitthvað innra með peim hreyft við peim með tilheyrandi sjálfsskoðun, sem varð til pess að pær tóku ákvörðun um að gera umfangsmiklar breytingar á starfsferli sínum. Hjá peim öllum var breytt ímynd, óvissa og/eða tekjutap meðal afleiðinganna. Hjá nokkrum viðmælendum ýttu aðdragandi og eftirköst efnahagshrunsins árið 2008 undir sjálfsskoðun peirra. Vangaveltur um tilgang, gildi og markmið voru áberandi.

Gunnhildur var líklega sá viðmælandi sem fór í mestu kúvendinguna. Hún stóð á fimmtugu pegar hún sagði upp eftir að hafa verið í árs leyfi. Pá var hún orðin uppgefin af álagi og pá sér í lagi andlegu álagi. Vanlíðanin fór stigvaxandi og síðustu árin vann hún á hörkunni. „,... petta starf er bara álag og menn bara fá allskonar mál upp í hendurnar sem bara taka úr manni sálina stundum. " Hanna var 51 árs pegar hún sagði starfi sínu lausu án pess að hafa annað í hendi. Hún lýsti miklu vinnuálagi eins og fleiri konur. Hún hafði alla starfsævina unnið á sama vinnustað og hugmyndin um að gera breytingar höfðu gerjast með henni í u.p.b. prjú ár. Spurningar sem leituðu á hana voru t.d. „Hver er ég?“ og: „Ætla ég að eyða allri starfsævinni á sama stað eða ætla ég að gera breytingar?" Birna var í starfsog rekstrarumhverfi sambærilegu pví sem Hanna sagði skilið við. Pær lýstu báðar mjög miklu brottfalli kvenna úr pessum starfsstéttum, sem eru afar karllægar.

Birna lýsti vinnuálaginu eins og Hanna og bætti við innbyrðis samkeppni. Hún fór í mikla sjálfsskoðun og velti pví fyrir sér hvert hún vildi stefna, hvað hún vildi gera og hvað skipti hana máli. Niðurstaðan var að hún vildi ekki purfa að leggja enn meira á sig til að ná árangri í vinnuumhverfi par sem magn vó pyngra en gæði. „Ég bara vildi fara.“ Líkt og Hanna sagði Birna skilið við starf sitt án pess að hafa annað í hendi. Lára hafði um langt skeið hugað að breytingum og gerði minniháttar breytingar á starfsvettvangi sínum í aðdraganda efnahagshrunsins og síðar miklar í kjölfar áfalls sem leiddi til heilsuleysis. Á hana leituðu spurningar á borð við: „Hvað langar mig til að gera í næsta kafla í lífinu?“ Jóhanna starfaði í sama geira og Lára og gerði til pess að gera litla breytingu á sínum starfsferli í aðdraganda hrunsins og svo aftur mikla eftir hrun, pegar hún sagði stjórnunarstarfi hjá fyrirtæki í fjármálageiranum lausu eftir mikla umhugsun án pess að hafa annað í hendi. Líkt og Lára fór hún í sjálfsskoðun síðar pegar hún fór að velta sínum gildum fyrir sér og máta sig við ólíkar sviðsmyndir. Fjóla starfaði á vettvangi tengdum peim sem Lára og Jóhanna störfuðu á og var í ábyrgðarmikilli stjórnunarstöðu. Hún hafði um talsvert skeið velt fyrir sér breyttum starfsvettvangi og lét verða af pví að stíga til hliðar í kjölfar efnahagshrunsins, en einnig vegna pess að hún varð fyrir persónulegu áfalli. Á hana leit- 
uðu spurningar eins og: „Er petta pað sem mig langar til að gera út lífið eða langar mig í eitthvað annað?" Hún fann að hennar persónulegu gildi og lífssýn ættu ekki endilega samleið með stjórnendateymi fyrirtækisins sem hún starfaði hjá. María átti að baki fjölbreyttan starfsferil og hafði í tvígang gert umfangsmiklar breytingar á sínum starfsferli. Pegar hún stóð á fertugu fór hún að velta fyrir sér hverju hún hefði áorkað á umliðnum áratug og hvað sá tími sem fram undan væri bæri í skauti sér. Clara var eini viðmælandinn sem gerði umfangsmikla breytingu á starfsferli sínum og tengir hana ekki við innri pælingar.

Fimm viðmælendanna störfuðu í fjármálageiranum aðdraganda eða kjölfar efnahagshrunsins, sem ýtti undir sjálfsskoðun peirra. Ein tilheyrði peim hópi viðmælenda sem gerði litla breytingu á sínum högum. Hinar fjórar tilheyrðu peim hópi sem gerði mikla breytingu. Enginn pessara viðmælenda greindi frá ólöglegu eða ósiðlegu athæfi, en pær lýstu aðstæðum og atburðarás sem hafi valdið peim ónotum og vakið pær til umhugsunar. Agnes sagði umfang og vöxt bankakerfisins hafa verið bæði mikinn og hraðan og að atburðarásin hafi verið gríðarlega hröð pegar ríkið tók yfir rekstur bankanna. „Velgengnin varð okkur að falli.“ Um aðstæður sagði hún: „En eitthvað af ógæfunni er að pað eru komnir einhverjir svona ... frekar ungir eða bara ungir strákar sem að leiða bankana." Lára greindi líka frá samkeppninni milli pessara priggja bankastjóra. Pegar hraðinn var hvað mestur var umhverfið farið að trufla hana. Hún sá ekki tilganginn og fannst starfið orðið innihaldslaust pegar markmiðin snerust um að stækka meira, kaupa meira og græða meira. Hún sagði skilið við bankann á hápunkti uppgangsins í efnahagslífinu. Hún lýsti ákveðnum aðskilnaði sem hafi átt sér stað pegar græðgin hafi verið orðin yfirgengileg. Jóhanna hætti „,...á hápunkti ruglsins“; „,... pað var bara allt í steik...“ ",...fólk var bara alveg að missa vitið og ég sko bara skildi ekkert hvað var í gangi“. Fjóla lýsti græðgi meðal stjórnenda í fyrirtækinu sem hún starfaði hjá sem varðaði kaupauka sem hún vildi afnema. „Við eigum bara að greiða laun og við eigum bara að hætta pessu rugli og pú veist við eigum ekki að láta græðgina stjórna okkur.“ Með pessu vildi hún sýna að stjórnendur fyrirtækisins væru ekki drifnir áfram af persónulegri græðgi og skapa pannig samfélagslega sátt og sýna samfélagslega ábyrgð. Pannig myndu stjórnendur sýna að peir hefðu hagsmuni viðskiptavina og starfsfólks að leiðarljósi sem henni fannst mikilvægt, ekki síst á pessum árum. Pá taldi hún að með kaupaukakerfinu yrði aðskilnaður milli starfsfólks og stjórnenda. Pessi sýn féll í grýttan jarðveg og kaupaukum var haldið til streitu.

\subsection{Heilsa og álag}

Ríflega helmingur viðmælenda greindi frá miklu vinnuálagi sem oft varð annað hvort beinlínis til pess að pær skiptu um starfsvettvang eða var áhrifapáttur. Ekki er hægt að tengja vinnuálag eða heilsubrest með afgerandi hætti við ákveðið undirmengi pátttakenda, t.d. aldur.

Katrín var á pessum tímamótum í sínu lífi á mörkum pess að brenna út vegna mikils álags og „,... algerlega orðin úrvinda." Gunnhildur, sem lýsti miklu andlegu álagi í starfi sínu, segist hafa verið komin nærri kulnun. Hanna og Birna, sem störfuðu á svipuðum vettvangi, lýstu báðar gegndarlausu vinnuálagi. Hanna fann jafnframt fyrir heilsuleysi sökum pess að hafa ávallt sett vinnuna í fyrsta sæti og hugsanir um mögulega kulnun leituðu á hana. „... í pessum geira eru náttúrulega brjálaðar kröfur.“ Vinnuálag ýtti við Birnu sem henni fannst ekki samræmast eigin markmiðum Agnes sagði vinnuna síðustu misserin hafa verið mikla. Hún hafði um nokkura ára skeið velt breytingum fyrir sér og vildi hætta á rekstrarlegum tímamótum, en var undir miklum prýstingi um að starfa áfram í geiranum. Í kjölfar hrunsins pyngist róðurinn enn frekar. „....ytra umhverfið var náttúrlega gersamlega vonlaust. "I ofanálag bættist persónulegt mótlæti við. Hún lýsir mánuðunum eftir hrun sem „hryllilega erfiðum[...] Eiginlega erfiðasta bara sem ég hef gert í lífinu.“ Og hún hugsaði: „Hver er ég eiginlega?“ Hanna talar um óreiðu í sínu lífi pegar allt gekk út á að vinna, sinna fjölskyldu og í ofanálag að vera góð mamma. „... pað lætur náttúrulega eitthvað undan. Pú getur ekki verið góður og bestur í öllu sko.“ Lára varð fyrir heilsutjóni 
og hún ákvað að stíga út af peirri starfsferilsbraut sem hún var á, fór úr hröđu samkeppnisumhverfi í að huga að heilsunni. Fjóla varð fyrir persónulegu áfalli. „... maður fer að hugsa pað aðeins öðruvísi. Er petta í alvöru bara pað eina sem skiptir máli?"

\subsection{Fjölbreytileiki og áhrifafjárfestingar}

Lára og Jóhanna höfðu lengi látið sig varða sjálfbærni og samfélagslega ábyrgð, sem pær tengdu við kvenleg gildi. Sjálfbærni og samfélagsleg ábyrgð er farin að vega æ pyngra hjá fjárfestum allra síðustu misserin, enda eru peir venjulegt fólk með siðferðiskennd sem láta sig ekki aðeins varða fjármuni heldur einnig siðferðileg og samfélagsleg málefni (Hart og Zingales, 2017). Pær voru jafnframt báðar meðvitaðar um að pað væri öllum fyrirtækjum nauðsynlegt að taka pessi skref, eins og Lára sagði:

Раð er pað sem er að gerast núna - pað sem er að breytast núna er að fjárfestar eru farnir að átta sig á pví að petta er leiðin til að búa til pening. En ástæðan fyrir að peir vilja fara pessa leið núna er að við sjáum að pað er hægt að græða meiri peninga á pví heldur en gera pað ekki.

Jóhanna er á sama máli og bætir pví við að pessi utanaðkomandi krafa væri orðin svo sterk að fyrirtæki fengju hvorki fjárfesta né starfsfólk nema bregðast við. Lára bætir við: "... fleiri svona "hardcore“ sem eru farnir að sjá ljósið í pessu. Í ljósi pví líka [sic] að ef við gerum ekki neitt. Pú veist eins og með loftslagsmálin og svona. Pá erum við bara „doomed"."

Lára leggur áherslu á mikilvægi fjölbreytileika pví pað muni skila meiri verðmætum. „....pað skiptir máli að fá konur að borðinu. Fyrirtæki sem hafa konur í stjórnum og konur sem eru að leiða fyrirtæki og annað ..." Hún sagði jafnari kynjahlutföll skapa aukið virði og aðra og heilbrigðari dýnamík." Hún vildi að forysta snerist meira um gildi, langtímahugsun, meðvitund, gagnsæi og mannlega pætti og hefur raunverulega starfað með pessi leiðarljós í meira en tíu ár. Jóhanna var farin að velta fyrir sér svipuðu, og tala fyrir pví, á svipuðum tíma og Lára. Hún sagði: „„.. sjálfbærnipælingar ... heimsmarkmiðin og petta.“

\section{Umræður og samantekt}

Prátt fyrir að rannsóknir bendi til pess að konum sé frekar mismunað pegar kemur að stjórnunarstörfum í efstu lögum skipulagsheilda (Bryman o.fl., 2011) er pað ekki upplifun kvennanna sem tóku pátt í pessari rannsókn. Рað kemur ekki á óvart vegna pess frama sem pær hafa náð í atvinnulífinu og upplifun peirra af karllægu starfsumhverfi er almennt jákvæð. Раð kann að styðja við niðurstöður Gipson o.fl. (2017) um að undirliggjandi hugmyndir, viðhorf og hugarfar um skilgreind kynjahlutverk hafi áhrif á upplifun á karla og kvenna og færni peirra og möguleikum í leiðtogahlutverkum.

Niðurstöður rannsóknarinnar ríma vel við fyrri erlendar rannsóknir á starfsvali og starfshvötum. Starfsferill er stór hluti af lífi fólks og getur veitt sjálfsfyllingu, áskoranir og tilgang. Starfsferillinn getur jafnframt verið uppspretta sjálfsmyndar, sköpunar, lífsáskorunar, samfélagsstöðu og félagslegs tengslanets (Defillippi og Arthur, 1994).

Konurnar sem tóku pátt í rannsókninni veltu talsvert fyrir sér tilgangi og gildum með spurningum á borð við: „Er petta pað sem mig langar til að gera?“ Samkvæmt niðurstöðum Thomas (1980) er innri vinnuhvati pað sem kemst næst pví að vera samnefnari fyrir starfsferilsbreytingar. Pátttakendur rannsóknar hans voru að bregðast við pví hvort gildi peirra og starfið gætu farið betur saman og að starfið fengi meiri pýðingu. Vangaveltur um gildi, markmið og tilgang eru áberandi meðal kvennanna sem gerðu mikla breytingu á sínum starfsferli - ekki síst meðal peirra sem störfuðu í fjármálatengdum fyrirtækjum og aðstæður voru pess eðlis að pessar vangaveltur kviknuðu. Sé litið til umfangs starfsferilsbreytinga má glöggt sjá að samband er á milli umfangs hvata og umfangs breytinga sem 
er í samræmi við kenningar Ibarra $(2005 ; 2015)$. Pær konur sem tóku pátt í rannsókninni og gerðu mikla breytingu á starfsferli sínum höfðu sterkari hvata. Peir gátu varðað andlega og líkamlega heilsu peirra eða starfsumhverfi sem samræmdist ekki gildum peirra og markmiðum. Nalis (2021) kemst að sömu niðurstöðu, en pær rannsóknir sýna að áföll sem tengdust gildum leiddu til mestu starfsferilsbreytinganna.

Vangaveltur viðmælenda ríma býsna vel við kenningar Ibarra um sjálfssprottna starfsferilsbreytingu, sem rædd var í kafla 2.2., par sem greina mátti samband á milli mikilla breytinga og pess að kafa ofan í sjálfsmyndina.. Petta rímar býsna vel við vangaveltur viðmælenda pví samband var á milli mikilla breytinga og pess að kafa ofan í sjálfsmyndina og spyrja spurninga á borð við: „Er petta pað sem ég vil gera?“ „Nærir petta gildin mín?“ o.s.frv.

Konunum sem tóku pátt í rannsókninni fannst lang flestum að kynferði sitt hefði ekki unnið gegn sér. Og pótt pær hafi ekki verið spurðar sérstaklega um breytingu á sjálfsöryggi í starfi með vaxandi aldri, bar starfsferill engra peirra merki pess, að aldur stæði peim fyrir prifum, nema síður sé. Petta er í samræmi við niðurstöður Zenger og Folkman (2019) og Ostrove o.fl. (2002) greindu aukið sjálfstraust kvenna á miðjum aldri, sem jafnvel óx umfram sjálfstraust karla á efri árum.

Kenning Lauru Carstensen (1995) um félagstilfinningaval getur skýrt margt. Engin kvennanna sem tóku pátt í rannsókninni er að kljást við að sinna grundvallarpörfinni að lifa af en glögg merki eru um að pær séu á hinum enda starfshvata sem tengist próun sjálfsvitundar. Meðal kvennanna sem tóku pátt í rannsókninni sést próun sjálfsvitundar í peirri djúpu sjálfsskoðun sem pær fóru í og tengdist t.d. meðvitund um heilsuleysi, mikilli vinnu, fjarveru frá fjölskyldu og pátttöku í verkefnum sem veittu takmarkaða lífsfyllingu. Rannsókn Carstensen o.fl. (1999) leiddi í ljós samhengi milli upplifunar einstaklinga á tíma og eftirfylgni félagslegra markmiða og pess að pekkingaröflun víkur fyrir auknu vægi tilfinningastjórnunar á miðjum aldri. (Carstensen, 1995; Carstensen o.fl., 1999). Pessi minnkandi áhersla á langtímamarkmið og aukna áhersla á tilfinningaleg markmið er grundvallarpáttur í niðurstöðu rannsóknarinnar, sem styður við rannsóknir Carstensen, 1995 og Carstensen o.fl., 1999. Konurnar sem tóku pátt í rannsókninni voru allar á eða yfir miðjum aldri og áherslur peirra hafa breyst.

Segja má að óefnislegar eignir kvennanna sem tóku pátt í rannsókninni séu í forgrunni og eins og heilsa, vinátta og fjölskylda (Gratton og Scott, 2016). Með pví að gera róttæka breytingu á starfsferli sínum voru viðmælendur að einhverju marki að færa fórnir. Tekjur minnkuðu og ímyndin breyttist gjarnan - sérstaklega hjá konunum sem gerðu mikla breytingu á sínum starfsferli. Lífsgæði peirra eru fremur fólgin í óefnislegum eignum en efnislegum. Niðurstöðurnar ríma við niðurstöðu Gratton og Scott (2016) og Kegan (1982), sem benti á að með auknum aldri hliðrist forgangsröðun fólks sem endi með pví að pað beini sjónum sínum að gildum og pví sem pað hefur áhuga á. Konurnar tengja sínar breytingar ekki við tiltekinn aldur, breytingaskeið eða tímamót heldur má segja að sjálfskoðun og innri pörf hafi vakið pær til vitundar um að vilja breyta.

Sé litið til lítillar pátttöku kvenna í æðstu stjórnunarstöðum getur maður ekki varist peirri hugsun að sumar skipulagsheildir gætu farið á mis við auðlindir pegar litið er til einsleitni á vettvangi forystu og pess sem virðist vera meira brottfall kvenna úr æðstu stjórnunarstörfum. Mikilvægt er fyrir atvinnulífið að huga að pví hvaða pættir í menningu fyrirtæka og stofnana ýtir undir brottfall kvenna úr æðstu stjórnunarstöðum. Efnahagsóvissan hopar fyrir óvissu um framtíð mannkyns en framfarir og hagfræði samtímans hefur átt hlutdeild í stórauknum ágangi á náttúru og auðlindir Jarðar. Ábyrgar fjárfestingar og ESG eru nýyrði í heimi viðskiptanna og er pað vettvangur par sem konur sækja fram. Á dögunum bárust alvarleg tíðindi frá fremstu vísindamönnum heims um loftslagsvána, sem kallar á tafarlaus viðbrögð (Intergovernmental Panel on Climate Change, 2021) og efnahagslegar breytingar. Pví er mikilvægt að fjölbreytt framtíðarsýn, markmið og gildi öðlist aukið vægi í málefnum framtíðarinnar. 
Mikilvægt er að skoða ofan í kjölinn hvað pað er sem skipulagsheildir geta gert til að vinna gegn brottfalli reynslumikilla kvenna úr forystu vegna pess hve pekking peirra og reynsla er dýrmæt.

\section{Heimildir}

Arnar Björnsson. (2021, 22. júní). Birna eina konan í karlaveldinu. RúV. https://www.ruv.is/frett/2021/06/22/ birna-eina-konan-i-karlaveldinu

Ásta Dís Óladóttir, Póra H Chrisiansen, Gylfi Dalmann Aðalsteinsson (2021). If Iceland is a Gender Paradise, Where are the Women CEOs of Listed Companies? Í Joan Marques (ritstj) Exploring Gender at work. Palgrave Macmillan. 317-337

Baruch, Y. (2004). Transforming careers: from linear to multidirectional career paths. Career Development International, 9(1), 58-73. https://doi.org/10.1108/13620430410518147

Boddy, C. R. (2016). Sample size for qualitative research. Qualitative Market Research, 19(4), 426-432. DOI 10.1108/QMR-06-2016-0053

Bryman, A., Collinson, D., Grint, K., Jackson, B. og Uhl-Bien, M. (2011). The SAGE Handbook of Leadership. SAGE.

Burk, S. og Collins, K. (2001). Gender differences in leadership styles and management skills. Women in Management Review, 16(5), (244-256). https://doi.org/10.1108/09649420110395728

Carless, S. og Arnup, J. (2011). A longitudinal study of the determinants and outcomes of career change. Journal of Vocational Behaviour, 78(1), 80-91. https://doi.org/10.1016/j.jvb.2010.09.002

Carstensen, L. (1995). Evidence for a life-span theory of socioemotional selectivity. American Psychological Society 4(5), 151-156. https://doi.org/10.1111\%2F1467-8721.ep11512261

Carstensen, L., Isaacowitz D. og Charles, S. (1999). Taking time seriously. A theory of socioemotional selectivity. American Psychologist, 54(3), 165-181. https://psycnet.apa.org/doi/10.1037/0003-066X.54.3.165

Defillippi, R. J. og Arthur, M. B. (1994). The boundaryless career: A competency-based perspective. Journal of Organizational Behaviour, 15(4), 307-324.

Dik, B. J. og Duffy, R. D. (2009). Calling and vocation at work: Definitions and prospects for research and practice. The Counselling Psychologist, 37(3), 424-450. https://doi.org/10.1177\%2F0011000008316430

Duffy, R. D. og Dik, B. J. (2009). Beyond the self: External influences in the career development process. The Career Development Quarterly, 58(1), 29-43. https://doi.org/10.1002/j.2161-0045.2009.tb00171.x

Elmuti, D., Jia, H. og Davis, H. (2009). Challenges women face in leadership positions and organizational effectiveness: An investigation. Journal of Leadership Education, 8(2), (167-187). http://dx.doi.org/10.12806/ $\mathrm{V} 8 / \mathrm{I} 2 / \mathrm{RF} 4$

Frkal, R. A. og Criscione-Naylor, N. (2020). Opt-out stories: womens's decisions to leave corporate leadership. Gender in Management: An International Journal, 36(1), 1-17. DOI 10.1108/GM-09-2019-0154

Fouad, N. A. og Bynner, J. (2008). Work transitions. American Psychologist, 63(4), 241-251. https://psycnet.apa. org/doi/10.1037/0003-066X.63.4.241

Gecas, V. (1982). The self-concept. Annual Review of Sociology, 8, (1-33). https://doi.org/10.1146/annurev. so.08.080182.000245

GemmaQ. (e.d.-a). GemmaQ ICE up when Islandsbanki listed on the stock market. https://gemmaq.org/newblog/2021/6/23/gemmaq-ice-up-when-islandsbanki-listed-on-the-stock-market

GemmaQ. (e.d.-b). Gender Lens for Global Markets. https://www.gemmaqratings.com/about-measures

Gipson, A. N., Pfaff, D. L., Mendelsohn, D. B., Catenacci, L. T. og Burke W. W. (2017). Women and leadership: Selection, development, leadership style, and performance. The Journal of Applied Behavioural Science, 53, 32-65. https://doi.org/10.1177\%2F0021886316687247

Gratton, L. og Scott, A. (2016). The 100-year life. Living and working in an age of longevity. Bloomsbury Information.

Guðbjörg Linda Rafnsdóttir, Ólöf Júlíusdóttir (2018). Reproducing gender roles through virtual work: The case of senior management. International Journal of Media \& Cultural Politics. 14 (1). 77-94.

Guðbjörg Linda Rafnsdóttir, Laufey Axelsdóttir, Sunna Diðriksdóttir, Porgerður Einarsdóttir (2015). Women and men as business leaders in Iceland. Jafnréttisstofa.

Hagstofa Íslands. (e.d.). Konur og karlar á Íslandi 2019. http://hagstofan.s3.amazonaws.com/media/public/2019/ f691d1ec-d651-4380-a68d-df7893e83e42.pdf

Hagstofa Íslands. (2020, 17. desember). Mannfjöldaspá 2020-2069. https:/www.hagstofa.is/utgafur/utgafa/ mannfjoldi/mannfjoldaspa-2020-2069/

Hagstofa Íslands. (2021, 14. apríl). Konur 34,1\% stjórnarmanna i fyrirtækjum með 50 launpega eða fleiri. https:// hagstofa.is/utgafur/frettasafn/fyrirtaeki/kyn-stjornarmanna/

Hanson, K. (2019, 8. mars). Why are there so many women in sustainable investing? NORDSHIP; Nordic Sustainable Investments. https://nordsip.com/2019/03/08/why-are-there-so-many-women-in-sustainable-investing/

Hart, O. og Zingales, L. (2017). Companies Should Maximize Shareholders Welfare Not Market Value. Journal 
of Law, Finance, and Accounting, 2(2), 247-274. https://scholar.harvard.edu/files/hart/files/108.00000022-hartvol2no2-jlfa-0022_002.pdf

Heppner, M. J., Multon, K. D. og Johnston, J. A. (1994). Assessing psychological resources during career change: Development of the career transitions inventory. Journal of Vocational Behaviour, 44(1), 55-74. https://doi. org/10.1006/jvbe.1994.1004

Herzberg, F., Mauser, B. og Snyderman, B. B. (1959). The motivation to work (2. útg.) New York: Wiley.

Ibarra, H. (2003). Working identity; Unconventional strategies for reinventing your career. Harvard Business School Press.

Ibarra, H. (2005). Identity Transitions: Possible selves, liminality and dynamics of career change. INSEAD. https:// flora.insead.edu/fichiersti_wp/inseadwp2005/2005-51.pdf

Ibarra, H. (2015). Impossible selves: Image strategies and identity threat in professional women's career transitions. INSEAD. https://dx.doi.org/10.2139/ssrn.2742061

IcelandSIF. (e.d.). Hugtök og skilgreiningar. https://www.icelandsif.is/\%C3\%A1byrgar-fj\%C3\%A1rfestingar/ hugtok-skilgreiningar/

Intergovernmental Panel on Climate Change. (2021). Climate Change 2021. The Physical Science Basis. Contribution of Working Group I to the Sixth Assessment Report on Climate Change. https://www.ipcc.ch/report/ar6/ wg1/downloads/report/IPCC_AR6_WGI_Full_Report.pdf

Jafnréttisstofa. (e.d.-a). Jafnlaunavottun. https://www.jafnretti.is/is/vinnumarkadur/jofn-laun-og-jafnir-moguleikar/hvad-er-jafnlaunavottun

Jafnréttisstofa. (e.d.-b). Lög um kynjakvóta í stjórnum. https://www.jafnretti.is/is/vinnumarkadur/jofn-medferda-vinnumarkadi/fjolbreytt-forysta/loggjof-um-kynjakvota-i-stjornum

Jafnréttisstofa. (e.d.-c). Betur má ef duga skal. https://www.jafnretti.is/is/um-jafnrettisstofu/greinar/betur-maef-duga-skal

Kegan, R. (1982). The evolving self; Problem and process in human development. Harvard University Press.

Kossek, E., Wu, L. og Su, R. (2017). “Opting-out" or "pushed-out"? Integrating perspectives on women's career equality for gender inclusion and interventions. Journal of Management, 43(1), 228-254. https://doi. org/10.1177\%2F0149206316671582

Lög um einkahlutafélög nr. 138/1994. https://www.althingi.is/lagas/151b/1994138.html

Lög um hlutafélög nr. 2/1995. https://www.althingi.is/lagas/nuna/1995002.html

Lög um jafna stöðu og jafnan rétt kynjanna nr. 150/2020. https://www.althingi.is/lagas/151b/2020150.html

Lög um sameignarfélög nr. 50/2007. https://www.althingi.is/lagas/151b/2007050.html

Lög um skuldutryggingu lífeyrisréttinda og starfsemi lífeyrissjóða nr. 129/ 1997. https://www.althingi.is/altext/stjt/1997.129.html

Mavin, S. (2001). Women's career in theory and practice: time for change? Women in Management Review, 16(4), 183-192. https://doi.org/10.1108/09649420110392163

Marsh og Bloomberg. (2020, 24. janúar). Responsible investing is a rare field of finance lead by women. Now it's hot - and men want in. Fortune. https://fortune.com/2020/01/24/responsible-esg-investing-women-finance/

Magnús H. Jónasson. (2021, 4. febrúar). Konur búa við lakara heilsufar og verri lífsgæði. Fréttablaðið. https:// www.frettabladid.is/frettir/konur-bua-vid-lakara-heilsufar-og-verri-lifsgaedi/

Merriam, S. (2009). Qualitative research: A guide to design and implementation (2. útgáfa). Jossey-

Bass.Nalis, I., Kubicek, B. og Korunka, C. (2021). From shock to shift-a qualitative analysis of accounts in mid-career about changes in the career path. Frontiers in Psychology, 12, 1-13. https://doi.org/10.3389/ fpsyg.2021.641248

Nelson, D. L. og Burke, R. J. (2000). Women executives: Health, stress, and success. Academy of Management Executive, 14 (2), 107-121. https://www.jstor.org/stable/4165639?seq=1\#metadata_info_tab_contents

OECD. (e.d.-a). Labour Force Participation Rate. https://data.oecd.org/emp/labour-force-participation-rate.htm

OECD. (e.d.-b). Life expectancy at birth. https://data.oecd.org/healthstat/life-expectancy-at-birth.htm

Olafsdottir, K. (2018). Iceland is the best but still not equal. Søkelys på arbeidslivet, 35(01-02), 111-126. http:// dx.doi.org/10.18261/issn.1504-7989-2018-01-02-07

Ólöf Júlísudóttir, Guðbjörg Linda Rafnsdóttir, Porbjörg Einarsdóttir (2018). Top managers and the gendered interplay of organizations and family life: The case of Iceland. Gender in Management: An International Journal. 33 (8).

Ostrove, J. M., Stewart, A. J. og Zucker, A. N. (2002). College-educated women's personality development in adulthood: Perception and age differences. Psychology and Aging, 17(2), 136-244. https://psycnet.apa.org/ doi/10.1037/0882-7974.17.2.236

Sandelowski, M. (1995). Focus on Qualitative Methods. Sample Size in Qualitative Research. Research in Nursing $\mathcal{E}$ Health,18, 179-183. https://doi.org/10.1002/nur.4770180211

Stjórnarskrá lýðveldisins Íslands nr. 33/1944. https://www.althingi.is/lagas/151b/1944033.html

Thomas, E. L. (1980). A typology of mid-life career changes. Journal of Vocational Behaviour, 16(2), 173-182. https://doi.org/10.1016/0001-8791(80)90048-2

Velferðarráðuneytið. (2018). Skýrsla félags- og jafnréttismálaráðherra um stöđu og próun jafnréttismála 2015-2017. https://www.stjornarradid.is/lisalib/getfile.aspx?itemid=33cbc9c1-217e-11e8-9429-005056bc530c 
66 | Tímarit um viðskipti og efnahagsmál

World Economic Forum. (2021, mars). Global Gender Gap Report 2021. http://www3.weforum.org/docs/WEF_ GGGR_2021.pdf

Zenger, J. og Folkman, J. (2019, 25. júní). Research: Women Score Higher Than Men in Most Leadership Skills. Harvard Business Review. https://hbr.org/2019/06/research-women-score-higher-than-men-in-most-leadership-skills

Zimmerman, L. M. og Clark, M. A. (2016). Opting-out and opting-in: a review and agenda for future research. Career Development International. 21(6), 603-633. DOI 10.1108/CDI-10-2015-0137

Porgerður Einarsdóttir. (e.d.). Ísland og kynjajafnréttið. Jafnréttisstofa. https://www.jafnretti.is/is/um-jafnrettisstofu/greinar/island-og-kynjajafnrettid

Póra H. Christiansen, Ásta Dís Óladóttir, Erla S. Kristjánsdóttir, Sigrún Gunnarsdóttir (2021). Forstjóraráđningar í pjóðhagslega mikilvægum fyrirtækjum: Kynjahalli, útilokun og ófagleg ráoningaferli? Stjórnmál og stjórnsýsla. 17(1). 107-129. 